\title{
AKTIVITAS ANTIDIABETES METABOLIT SEKUNDER BAKTERI ENDOFIT ASAL KULIT KAYU MANIS
}

\section{(ANTIDIABETIC ACTIVITY FROM SECONDARY METABOLIM ENDOPHYTIC BACTERIA BARK)}

\author{
Purbowatiningrum Ria Sarjono, Hendra Dwipa Rifky Mahardika, Nies S. Mulyani, \\ Ngadiwiyana., Nor Basid Adi Prasetyawibowo, dan Ismiyarto \\ Departemen Kimia, Fakultas Sains dan Matematika, Universitas Diponegoro \\ Jl. Prof. Sudharto SH., Tembalang, Semarang 50275 \\ Coressponding author: ismiyarto@live.undip.ac.id
}

\begin{abstract}
Abstrak
Penelitian ini bertujuan untuk mengisolasi bakteri endofit yang bersimbiosis dengan kulit kayu manis, mendapatkan data kemampuan inhibisi enzim $\alpha$-glukosidase dari metabolit sekunder isolat bakteri endofit yang didapatkan, serta mendapatkan informasi mengenai kandungan kimia dari metabolit sekunder isolat bakteri endofit yang didapat. Bahan yang digunakan pada penelitian ini terdiri atas sampel kulit kayu manis (Cinnamomum burmanii) yang didapatkan dari daerah Kopeng, Kabupaten Semarang. Metode yang digunakan dalam sterilisasi adalah metode klorin. Pengamatan morfologi koloni dilakukan dengan pewarnaan gram sedangkan Uji Inhibisi $\alpha$-glukosidase dari metabolit menggunakan metode dari Sancheti. Aktivitas antidiabetes diuji menggunakan metode penghambatan enzim $\alpha$-glukosidase. Hasil yang diperoleh pada penelitian ini adalah lima isolat bakteri memiliki yang bentuk beragam yakni streptobacillus (isolat $\mathrm{C} 1$, isolat $\mathrm{C} 4$, dan isolat $\mathrm{C5}$ ), diplobacillus (isolat $\mathrm{C} 2$ ), dan diplococcus (isolat $\mathrm{C} 3$ ). Kemampuan inhibisi $\alpha$-glukosidase tertinggi dihasilkan oleh metabolit sekunder isolat C5 yakni sebesar 45,634\% pada konsentrasi 100 ppm. Penapisan fitokimia pada penelitian ini menunjukkan bahwa metabolit sekunder isolat C5 yang memiliki daya inhibisi tertinggi mengandung senyawa flavonoid, tanin, kuinon dan saponin.
\end{abstract}

Kata kunci: kulit kayu manis, bakteri endofit, metabolit sekunder, enzim a-glukosidase

\begin{abstract}
This study was aimed at isolating endophytic bacteria symbiotic with cinnamon bark, obtaining data on the inhibition ability of $\alpha$-glucosidase enzymes from secondary metabolites of endophytic bacterial isolates obtained, and obtaining information on the chemical content of secondary metabolites of endophytic bacterial isolates obtained. The materials used in this study consisted of the samples of cinnamon bark (Cinnamomum burmanii) obtained from Kopeng, Semarang. The method used in sterilization was the chlorine method. Colony morphological observations were carried out by using gram staining, while the $\alpha$-glucosidase inhibition test of metabolites used the Sancheti method. The antidiabetic activity was tested using the $\alpha$-glucosidase enzyme inhibition method. The results show that five bacterial isolates had various forms, namely streptobacillus (isolate $\mathrm{C} 1$, isolate $\mathrm{C} 4$, and isolate $\mathrm{C} 5$ ), diplobacillus (isolate C2), and diplococcus (isolate C3). The highest $\alpha$-glucosidase inhibition ability was produced by secondary metabolites of isolate C5, namely $45.634 \%$ at a concentration of 100 ppm. Phytochemical screening in this study showed that the secondary metabolites of isolate C5 which had the highest inhibitory power contained flavonoids, tannins, quinones and saponins.
\end{abstract} Keywords: cinnamon bark, endophyte bacteria, secondary metabolites, $\alpha$-glucosidase enzyme 


\section{PENDAHULUAN}

Diabetes mellitus (DM) merupakan suatu kelainan metabolisme karbohidrat kronis serius yang memiliki dampak signifikan terhadap kesehatan seseorang. DM terjadi ketika konsentrasi glukosa dalam darah secara kronis lebih tinggi daripada nilai normal (hiperglikemia) akibat tubuh kekurangan insulin atau fungsi insulin tidak efektif (Subroto, 2006). Salah satu metode pengobatan penyakit diabetes mellitus yang sedang berkembang saat ini adalah penghambatan aktivitas enzim $\alpha$-glukosidase dengansuatusenyawainhibitor $\alpha$-glukosidase. Inhibitor $\alpha$-glucosidase digambarkan sebagai yang paling efektif dalam mengurangi hiperglikemia pasca-prandial (PPHG) dari semua obat anti-diabetes yang tersedia yang digunakan dalam pengelolaan diabetes mellitus tipe 2. Saat ini, beberapa obat oral digunakan seperti vogli-bose, acarbose, dan miglitol untuk menghambat aktivitas a-glukosidase (Proença et al., 2017). Glucobay adalah contoh obat di pasaran yang mengandung akarbose sebagai senyawa inhibitor $\alpha$-glukosidase.

Inhibitor $\alpha$-glukosidase adalah senyawa yang mampu menginhibisi metabolisme karbohidrat kompleks menjadi glukosa dalam usus kecil. Aktivitas dari senyawa inhibitor $\alpha$-glukosidase akan mengurangi jumlah glukosa yang masuk dari usus ke darah. Dengan aktivitas tersebut, senyawa ini mam- pu mengurangi peningkatan kadar glukosa darah pada penderita diabetes (Depkes RI, 2005). Senyawa inhibitor $\alpha$-glukosidase bisa diisolasi dari tumbuhan maupun mikroba endofit yang bersimbiosis dengan tumbuhan tersebut (Pujiyanto, Lestari, Suwanto, Budiarti, \& Darusman, 2012).

Bakteri endofit merupakan bakteri yang hidup secara simbiosis di dalam jaringan tanaman inangnya dan tidak memberikan efek negatif terhadap tanaman tersebut (Anjum, Ansari, Naquvi, \& Arora, 2013). Sebagaimana inangnya, populasi bakteri endofit juga sangat dipengaruhi oleh kondisi lingkungan dan lokasi tanaman inang tumbuh. Simbiosis mutualisme antara bakteri endofit dan tanaman inang memungkinkan bakteri endofit menghasilkan senyawa bioaktif serupa seperti tanaman inangnya (Guo, Wang, Sun, \& Tang, 2008) yang berguna untuk pertumbuhan dan perlindungan diri bakteri tersebut serta melindungi tanaman inang terhadap ancaman kondisi lingkungan disekitar (Nair \& Padmavathy, 2014). Senyawa bioaktif dari bakteri endofit sangat berpotensi untuk dikembangkan dalam bidang medis, industri dan pertanian (Pimentel-Elardo et al., 2011).

Tanaman kayu manis (Cinnamomum burmanii) merupakan tanaman penghasil senyawa inhibitor $\alpha$-glukosidase (Vangalapati, Satya, Prakash, \& Avanigadda, 2012). Penelitian Ngadiwiyana, Ismiyarto, Prasetya, 
dan Purbowatiningrum (2011) menunjukkan bahwa senyawa sinamaldehid yang diisolasi dari minyak kayu manis perdagangan dengan konsentrasi 50 ppm menghasilkan daya inhibisi sebesar 93,29\% terhadap enzim $\alpha$-glukosidase. Penelitian Ping, Zhang, dan Ren (2010) dengan menggunakan tikus diabetes, menemukan bahwa pemberian minyak kayu manis secara oral dengan dosis $100 \mathrm{mg} / \mathrm{kg}$ selama 35 hari dapat menurunkan kadar glukosa dalam darah tikus secara signifikan yakni $2 \mathrm{mmol} / \mathrm{L}$. Penelitianpenelitian tersebut telah memberikan bukti bahwa tanaman kayu manis dapat berfungsi sebagai obat antidiabetes.

Penelitian ini bertujuan mengisolasi bakteri endofit yang bersimbiosis dengan kulit kayu manis, mendapatkan data kemampuan inhibisi enzim $\alpha$-glukosidase dari metabolit sekunder isolat bakteri endofit yang didapatkan, serta mendapatkan informasi mengenai kandungan kimia dari metabolit sekunder isolat bakteri endofit yang didapat.

Diharapkan melalui metode ini dapat diperoleh metabolit sekunder dari bakteri endofit yang mempunyai aktifitas antidiabetes. Selain itu metode ini akan membantu pelestarian tanaman kayu manis dan mempersingkat waktu produksi komponen bioaktif yang sama dengan kayu manis sebagai obat antidiabetes.

\section{METODOLOGI PENELITIAN}

Alat-alat yang digunakan pada penelitian ini terdiri atas erlenmeyer $250 \mathrm{~mL}$ (Pyrex), gelas ukur 100 mL (Pyrex), gelas beker 1000 mL (Herma), 500 mL (Pyrex), 50 mL(Pyrex), neraca analitik, inkubator, spirtus, pengaduk, kaca arloji, kawat ose, mikro pipet, shaker, inkas, sentrifuge (Hettich Zentrifugen Micro 200R), dan autoklaf (Clinical Autoclave Prestige Medical Series 2100).

Bahan yang digunakan pada penelitian ini terdiri atas sampel kulit kayu manis, media Yeast Malt Agar (YMA), pepton, dan soluble starch. Enzim $\alpha$ - glukosidase (Sigma; USA), $\mathrm{Na}_{2} \mathrm{CO}_{3}$, DMSO, Bufer fosfat (Larutan A $\mathrm{NaH}_{2} \mathrm{PO}_{4}$ dan $\mathrm{B} \mathrm{Na}_{2} \mathrm{HPO}_{4}$ ), Acarbose (Glucobay), HCl, Safranin, alkohol aseton, lugol iodin, pewarna kristal ungu violet, metanol, $\mathrm{HCl}$, asam klorida $2 \mathrm{~N}$, amoniak 25\%, kloroform, pereaksi Dragendorff (bismut nitrat dan merkuri klorida dalam nitrit berair), pereaksi Meyer (kalium iodida dan merkuri klorida), serbuk magnesium, asam klorida pekat, besi (III) klorida, gelatin, anhidrida asam asetat, amil alkohol, eter, asam sulfat pekat, dan p-nitrofenil $\alpha$-D glukopiranosida.

\section{Preparasi dan Sterilisasi Sampel.} Bahan baku berupa kulit kayu manis yang masih segar dan belum dikeringkan, sehingga masih terdapat mikroba endofitik yang hidup di dalamnya. Pohon kayu manis 
tersebut didapatkan dari daerah Kopeng, Kabupaten Semarang.

Metode yang digunakan dalam sterilisasi adalah metode klorin (Nurkanto, Rahmansyah, \& Kanti, 2008). Sampel disterilisasi permukaan dengan cara merendamnya dalam akuades steril selama 2 menit dan digojog, kemudian dilanjutkan dengan perendaman pada alkohol $70 \%$ selama 60 detik.

Langkah berikutnya adalah pencucian kembali dengan akuades steril kemudian dilanjutkan dengan perendaman dalam $\mathrm{CaOCl} 5.25 \%$ selama 3 menit. Sterilisasi diakhiri dengan pembilasan menggunakan akuades steril. Kulit kayu manis yang telah steril permukaannya lalu ditumbuk menggunakan mortar steril untuk mendapatkan ekstrak dari kulit kayu manis tersebut.

Isolasi Bakteri Endofit. Ekstrak kulit kayu manis yang telah didapat selanjutnya ditanam pada permukaan media YMA secara aseptik. Media yang telah berisi sampel tersebut kemudian diinkubasi pada suhu ruang selama tiga hari. Koloni bakteri yang tumbuh kemudian dipisahkan menurut kenampakan morfologisnya. Isolat bakteri yang telah dipisahkan selanjutnya diuji dengan pewarnaan gram dan ditanam pada media cair untuk diproduksi metabolit sekundernya.

Perwarnaan Gram Isolat. Pengamatan morfologi koloni dilakukan dengan pewarnaan gram (Cappuccino \& Shermann, 1992).
Satu ose isolat bakteri endofit disuspensikan ke dalam akuades steril dan difiksasi di atas kaca benda bersih. Olesan bakteri diberi 2-3 tetes pewarna Kristal violet (gram A) dan dibiarkan selama 1 menit. Zat warna berlebih dicuci dengan air mengalir dan dikeringanginkan. Olesan bakteri digenangi dengan 2 tetes larutan lugol iodin (gram B), dibiarkan selama 1 menit. Zat warna berlebih dicuci dengan air mengalir dan dikeringanginkan. Olesan dicuci dengan larutan alkohol aseton (gram C) selama 30 detik. Zat pewarna berlebih dibilas dengan air mengalir dan dikeringanginkan. Olesan diberi cat safranin (gram D) selama 2 menit, dicuci dengan air mengalir dan dikeringanginkan. Preparat diamati di bawah mikroskop dengan perbesaran kuat (1000x) menggunakan minyak emersi.

\section{Kultur Pertumbuhan Isolat Bakteri} endofit. Isolat bakteri diambil dengan kawat ose steril dan dimasukkan dalam media cair $100 \mathrm{ml}$. Media cair yang digunakan mengandung pepton, soluble starch, yeast dan akuades (Chen, Yan, Lin, Zheng, \& Zhang, 2004). Inkubasi dilakukan pada suhu ruang menggunakan inkubator bergoyang dengan kecepatan $75 \mathrm{rpm}$ selama 7 hari (Pujiyanto \& Ferniah, 2010). Kultur disentrifugasi $4000 \mathrm{rpm}$ pada suhu $4^{\circ} \mathrm{C}$ selama 15 menit. Filtrat dari kultur ini selanjutnya dipekatkan menggunakan freeze dryer. Residu yang diperoleh merupakan 
metabolit sekunder yang digunakan untuk menentukan daya hambat larutan tersebut terhadap aktivitas enzim alfa glukosidase.

Uji Inhibisi $\alpha$-glukosidase darimetabolit sekunder. Uji Inhibisi $\alpha$-glukosidase dari metabolit menggunakan metode dari Sancheti, Sancheti, dan Seo (2009). Setiap residu hasil pengeringan media cair dibuat larutan induk $100 \mathrm{ppm}$. Setiap residu diencerkan menjadi 50; 25; 12,5; dan 6,25 ppm. Setiap konsentrasi residu dipipet sebanyak $10 \mu \mathrm{L}$ ke dalam microplate ditambahkan $25 \mu \mathrm{L}$ substrat ( $p$-nitrophenil$\alpha$-D-glukopiranosida), $50 \mu \mathrm{L}$ buffer posfat $\mathrm{pH} 7.0$, dan $25 \mu \mathrm{L}$ enzim $\alpha$-glukosidase, kemudian diinkubasi selama 30 menit pada suhu $37^{\circ} \mathrm{C}$. Reaksi enzim dihentikan dengan penambahan $100 \mu \mathrm{L} \mathrm{Na}_{2} \mathrm{CO}_{3}$ dan dibaca absorbansinya pada panjang gelombang $410 \mathrm{~nm}$. Tabel 1 menyajikan sistem reaksi penentuan inhibisi metabolitsekunder bakteri endofit terhadap enzim $\alpha$-glukosidase.

Aktivitas enzim diukur berdasarkan hasil absorbansi $p$-nitrofenol. Apabila sampel memiliki kemampuan menghambat aktivitas enzim $\alpha$-glukosidase, maka $p$-nitrofenol yang dihasilkan akan berkurang. Apabila nilai absorbansi $p$-nitrofenol tinggi, kemampuan inhibisi dari sampel rendah. Sebaliknya, jika nilai absorbansi dari $p$-nitrofenol rendah, kemampuan inhibisi yang dimiliki sampel tinggi. Daya inhibisi dapat dihitung dari persamaan:

$\%$ inhibisi $=\frac{\text { (Absorbansi blanko-Absorbansi sampel) }}{\text { Absorbansi blanko }} \times 100$

Penapisan Fitokimia. Penapisan fitokimia berdasar metode yang digunakan oleh Farnsworth (1966) dilakukan pada residu pengeringan media cair bakteri endofit kulit kayu manis dan simplisia kulit kayu manis.

Uji Alkaloid. Sebanyak $1 \mathrm{~g}$ sampel uji ditambahkan dalam $10 \mathrm{~mL}$ kloroform lalu penambahan 5 tetes $\mathrm{NH}_{4} \mathrm{OH}$, campuran disaring dan filtratnya dikocok dengan penambahan 10 tetes $\mathrm{H}_{2} \mathrm{SO}_{4} 2 \mathrm{M}$. Kemudian lapisan asam (atas) dibagi menjadi dua ke dalam tabung reaksi. Tabung pertama ditetesi dengan pereaksi Dragendorff dan uji positif

\section{Tabel 1}

Sistem Reaksi Penentuan Inhibisi Metabolit Sekunder Bakteri Endofit terhadap Enzim a-G,lukosidase

\begin{tabular}{lccc}
\hline & $\begin{array}{c}\text { Blanko } \\
(\mu \mathrm{L})\end{array}$ & $\begin{array}{c}\text { Kontrol Negatif } \\
(\mu \mathrm{L})\end{array}$ & $\begin{array}{c}\text { Sampel } \\
(\mu \mathrm{L})\end{array}$ \\
\hline Larutan metabolit sekunder & - & 10 & 10 \\
Buffer & 25 & 25 & 25 \\
Substrat (p-nitrophenil- $\alpha$-D-glukopiranosida) & 25 & 25 & 25 \\
Enzim $\alpha$-glukosidase & 25 & - & 25 \\
Inkubasi pada suhu 370 C selama 30 menit & & & \\
$\mathrm{Na}_{2} \mathrm{CO}_{3}$ & 100 & 100 & 100 \\
\hline
\end{tabular}


ditandai dengan terbentuknya warna merah atau jingga. Tabung kedua ditambahkan setetes pereaksi Meyer. Terbentuknya kabut putih hingga endapan putih menunjukkan adanya alkaloid.

Uji Flavonoid. Sebanyak $0,5 \mathrm{~g}$ sampel ditambahkan $10 \mathrm{~mL}$ metanol dan $10 \mathrm{~mL}$ akuades kemudian disaring. Lalu ditambahkan $5 \mathrm{~mL}$ eter kemudian dikocok dan didiamkan. Ambil lapisan metanol dan uapkan pada suhu $40^{\circ} \mathrm{C}$ kemudian larutkan dalam $5 \mathrm{~mL}$ etil asetat; penambahan 1 $\mathrm{mL}$ etanol; ditambahkan $0,1 \mathrm{~g}$ serbuk magnesium; $1 \mathrm{~mL}$ asam klorida pekat lalu dikocok kuat-kuat; dan dibiarkan memisah. Adanya flavonoid ditunjukkan dengan timbulnya warna merah, kuning.

Uji Saponin. Sebanyak 0,5 g sampel ditambahkan $10 \mathrm{~mL}$ akuades panas dan didihkan selama 10 menit lalu disaring, kemudian dikocok kuat secara vertikal selama 10 detik. Adanya saponin ditandai dengan terbentuknya busa setinggi $1-10 \mathrm{~cm}$ yang stabil sekitar 10 menit dan tidak hilang ketika ditambahkan 1 tetes asam klorida $2 \mathrm{~N}$.

Uji Tanin. Sebanyak $1 \mathrm{~g}$ sampel ditambahkan $10 \mathrm{~mL}$ akuades panas dan didihkan selama 10 menit lalu di saring, ditambahkan larutan besi (III) klorida $1 \%$. Adanya tanin bebas ditandai dengan terbentuknya warna hijau kehitaman.

Uji Triterpenoid/Steroid. Sebanyak 2 g sampel ditambahkan dengan $5 \mathrm{~mL}$ etanol panas selama 1 jam, kemudian disaring dan residunya di tambahkan eter. Ekstrak ditambahkan 3 tetes anhidrida asam asetat dan 1 tetes asam sulfat pekat ke plat tetes. Adanya steroid ditunjukkan jika terbentuk warna biru atau ungu, sedangkan bila terbentuk warna merah menandakan adanya triterpenoid.

\section{HASIL DAN PEMBAHASAN}

Isolasi Bakteri Endofit. Sampel yang digunakan adalah kulit kayu manis yang masih segar. Pemilihan sampel yang masih segar dimaksudkan agar bakteri didapatkan bakteri endofit dalam keadaan hidup. Sterilisasi perlu dilakukan karena ingin mendapatkan bakteri endofit yang berasal dari kayu manis. Langkah-langkah awal adalah sterilisasi, diharapkan dapat mencegah tumbuhnya mikroba yang berasal dari lingkungan. Metode sterilisasi dan penanaman dalam penelitian ini merujuk pada metode yang digunakan oleh Nurkanto dkk (2008); Kafur dan Khan (2011).

Hasil yang diperoleh dari proses ini adalah ekstrak kasar dari kulit kayu manis yang berwarna kecoklatan dan berlendir seperti tampak pada Gambar 1. Ekstrak kayu manis yang didapat selanjutnya digunakan pada tahap berikutnya yaitu isolasi bakteri endofit pada media Yeast Malt Extract Agar (YMA).

Tahap isolasi bakteri endofit bertujuan untuk memperoleh isolat bakteri endofit yang 


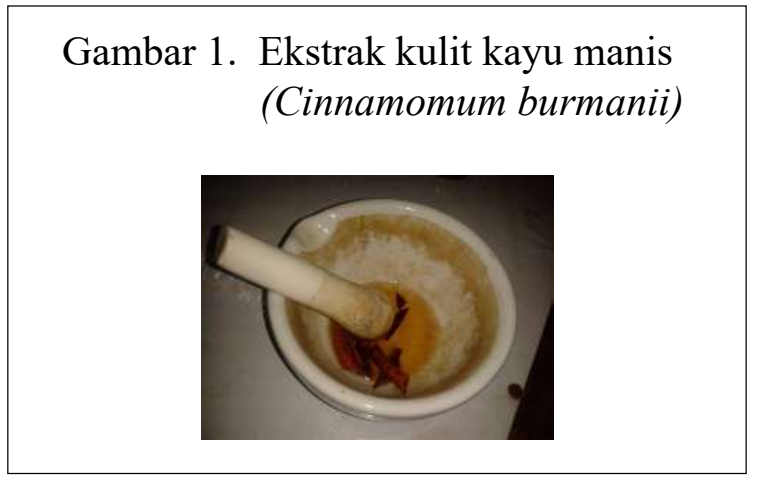

berasal dari kulit kayu manis (Cinnamomum burmannii). Langkah awal dari tahapan ini adalah pembuatan media YMAsebagai media padat untuk mengisolasi bakteri endofit dari sampel kayu manis. Media ini berisi yeast extract, malt extract, dextrose,dan agar bakteriologi. Dextrose dan malt extract berfungsi sebagai sumber karbon sedangkan yeast extract sebagai sumber nitrogen yang diperlukan mikroba untuk tumbuh. Kontrol negatif yang digunakan hanya berisi media YMA tanpa ekstrak kayu manis.

Bakteri tumbuh pada hari ketiga inkubasi. Pada awal inokulasi bakteri endofit dari kulit kayu manis menghasilkan lima jenis koloni yang berbeda penampakan fisiknya.
Bakteri yang tumbuh selanjutnya dipisahkan berdasar perbedaan penampakan fisiknya. Pemisahan tersebut harus segera dilakukan untuk menghindari tumbuhnya kontaminan. Pemisahan pada awal fase tumbuh juga dimaksudkan agar saat pemindahan ke media yang baru tidak terlalu mendekati fase kematian. Lima jenis koloni yang didapatkan selanjutnya dipisahkan menggunakan media YMA untuk mendapatkan isolat yang berbeda jenis spesiesnya. Isolat yang sudah dipisahkan selanjutnya dilihat karakter morfologisnya dengan pewarnaan gram.

Tujuan dari pewarnaan gram pada penelitian ini adalah memastikan bahwa kelima isolat yang dipilih memiliki bentuk morfologis yang berbeda. Hasil pewarnaan gram dapat dilihat pada Tabel 2 .

Pengamatan hasil dari pewarnaan gram dilakukan pada mikroskop dengan perbesaran 1000x. Kelima bakteri endofit yang diperoleh adalah jenis bakteri gram negatif dengan bentuk isolat yang kesemuanya berbeda. Perbedaan bakteri

Tabel 2

Penampakan Morfologis Isolat Bakteri Endofit Kayu Manis

\begin{tabular}{|c|c|c|c|c|c|}
\hline $\begin{array}{c}\text { Karakter } \\
\text { Koloni }\end{array}$ & $\mathrm{C} 1$ & $\mathrm{C} 2$ & C3 & $\mathrm{C} 4$ & $\mathrm{C} 5$ \\
\hline Warna & kecoklatan & $\begin{array}{l}\text { putih ke- } \\
\text { kuningan }\end{array}$ & kekuningan & kecoklatan & putih \\
\hline $\begin{array}{l}\text { Bentuk } \\
\text { Koloni }\end{array}$ & bulat & bulat & lonjong & bulat & lonjong \\
\hline Elevasi & halus & halus & halus & bergerigi & halus \\
\hline $\begin{array}{l}\text { Bentuk sel } \\
\text { Jenis Gram } \\
\text { Bakteri }\end{array}$ & $\begin{array}{l}\text { streptobacillus } \\
\text { negatif }\end{array}$ & $\begin{array}{l}\text { diplobacillus } \\
\text { negatif }\end{array}$ & $\begin{array}{l}\text { diplococcus } \\
\text { negatif }\end{array}$ & $\begin{array}{l}\text { streptobacillus } \\
\text { negatif }\end{array}$ & $\begin{array}{l}\text { streptobacillus } \\
\text { negatif }\end{array}$ \\
\hline
\end{tabular}


gram negatif dan bakteri gram positif terletak pada struktur dinding selnya. Bakteri gram negatif memiliki lapisan lipid yang lebih tebal daripada lapisan peptidoglikan pada dinding sel. Lapisan lipid tersebut akan larut saat penambahan alkohol sehingga sampel isolat menjadi tak berwarna. Perubahan tersebut dikarenakan ikatan pada peptidoglikan bakteri gram negatif tidak kuat sehingga setelah lipid larut dengan alkohol pori-pori dari dinding sel mengembang dan zat warna dapat keluar dari dinding sel (Pelczar \& Chan, 2008). Isolat berwarna merah setelah ditambahkan safranin untuk pewarnaan sel yang kedua. Warna merah tersebut terbentuk karena safranin menempati pori-pori dinding sel yang sudah terbuka dan tidak terisi oleh pewarna ungu violet. Hasil pewarnaan akan berbeda apabila bakteri yang dianalisis merupakan bakteri gram positif. Bakteri gram negatif memiliki lapisan lipid yang lebih tebal daripada lapisan peptidoglikan pada dinding sel.

Penampakan mikroskopis dari isolat C1, C4, dan C5 memiliki kemiripan pada pola penataan dirinya yakni berbentuk rantai dan tidak bergerombol. Pola penataan tersebut menunjukkan bahwa ketiga isolat tersebut merupakan jenis streptobacillus. Penampakan mikroskopis dari isolat $\mathrm{C} 2$ mendekati pola penataan dari jenis bakteri diplobacillus yakni berpasangan dan hidup secara bergerombol. Pada isolat $\mathrm{C} 3$ terlihat bahwa bakteri berbentuk bulat (kokus). Pola penataan dari isolat $\mathrm{C} 3$ menunjukkan adanya bakteri berbentuk bulat berpasangan yang dikenal dengan bakteri jenis diplococcus. Hasil penampakan mikroskopis juga menunjukkan bahwa isolat $\mathrm{C} 1, \mathrm{C} 2, \mathrm{C} 3, \mathrm{C} 4$, dan C5 memiliki bentuk morfologis yang berbeda sehingga kemungkinan berasal dari spesies yang berbeda pula. Perbedaan spesies akan menyebabkan perbedaan pada aktivitas antidiabetes dari metabolit yang dihasilkan.

Kultur Bakteri Endofit. Tahap kultur pertumbuhan isolat bakteri endofit bertujuan untuk memproduksi metabolit sekunder yang diharapkan memiliki aktivitas inhibitor $\alpha$-glukosidase. Tahap pengkulturan bakteri endofit kayu manis menggunakan metode dari Chen et al. (2004). Media cair yang digunakan mengandung yeast, pepton, soluble starch, dan akuades. Yeast dan pepton merupakan sumber nitrogen, sedang-kan soluble starch berfungsi sebagai sumber karbon yang digunakan mikroba untuk tumbuh. Karbon merupakan senyawa yang digunakan sebagai penyusun utama sel, sedangkan nitrogen digunakan mikroba sebagai bahan untuk mensintesis asam-asam amino.

Kultur isolat bakteri endofit tersebut kemudian disentrifugasi pada kecepatan 4000 rpm selama 20 menit pada suhu $4^{\circ} \mathrm{C}$. Proses sentrifugasi bertujuan untuk mendapatkan filtrat yang mengandung senyawa metabolit sekunder dari bakteri endofit kulit kayu 
manis. Filtrat kemudian dikeringkan dengan freeze dryer. Residu hasil pengeringan merupakan metabolit sekunder isolat bakteri endofit. Pada tahap ini diperoleh metabolit sekunder dari masing-masing bakteri. Tabel 3 menunjukkan bahwa massa yang diperoleh hamper sama untuk metabolit sekunder dari masing-masing bakteri.

Tabel 3

Massa Metabolit Sekunder Bakteri Endofit Kulit Kayu Manis

\begin{tabular}{cc}
\hline Isolat bakteri & $\begin{array}{c}\text { Massa Metabolit } \\
\text { (gram) }\end{array}$ \\
\hline $\mathrm{C} 1$ & 1,56 \\
$\mathrm{C} 2$ & 1,23 \\
$\mathrm{C} 3$ & 1,75 \\
$\mathrm{C} 4$ & 1,33 \\
$\mathrm{C} 5$ & 1,40 \\
\hline
\end{tabular}

\section{Uji Aktivitas Antidiabetes Metabolit} Sekunder Isolat melalui Mekanisme Inhibisi $\alpha$-Glukosidase. Tahap ini bertujuan untuk mendapatkan data aktivitas antidiabetes metabolit sekunder dari isolat bakteri endofit yang didapatkan. Metode pengujian dilakukan secara in vitro yakni melalui mekanisme inhibisi enzim $\alpha$-glukosidase terhadap substrat $p$-nitrofenil $\alpha$ - D- glukopiranosida. Mekanisme reaksi dari hidrolisis substrat $p$ nitrofenil $\alpha$-D- glukopiranosida oleh enzim $\alpha$-glukosidase dapat dilihat pada Gambar 2.

Pada Gambar 3 dapat dilihat bahwa metabolit sekunder bakteri endofit C5 memiliki kemampuan inhibisi $\alpha$-glukosidase tertinggi yakni sebesar $45,634 \%$ pada konsentrasi 100 ppm. Data tersebut menunjukkan bahwa senyawa metabolit sekunder yang dihasilkan oleh isolat bakteri endofit C5 mampu menginhibisi 45,634\% aktivitas dari $\alpha$-glukosidase. Senyawa yang digunakan sebagai pembanding pada pengujian ini adalah Glucobay. Pada pengujian ini Glucobay memiliki kemampuan inhibisi sebesar $94,831 \%$ pada konsentrasi 10 ppm. Perbedaan kemampuan inhibisi dari metabolit sekunder dan Glucobay disebabkan Glucobay mengandung senyawa

Gambar 2. Persamaan Reaksi Enzimatik $\alpha$ - Glukosidase dan $p$-Nitrofenil- $\alpha$-D Glukopiranosida

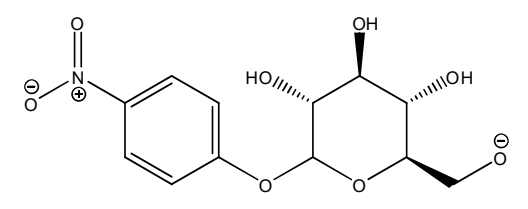

p-nitrofenil- $\alpha$-D-glukopiranosida

Sumber: Sugiwati, 2005

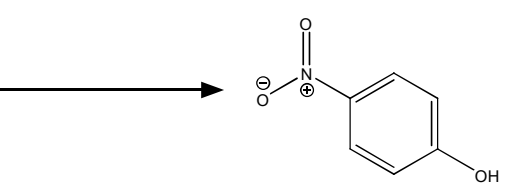

p-nitrofenol

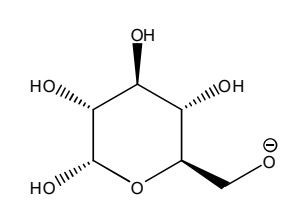

a-D-glukosa

Sumber: Sugiwati, 2005 


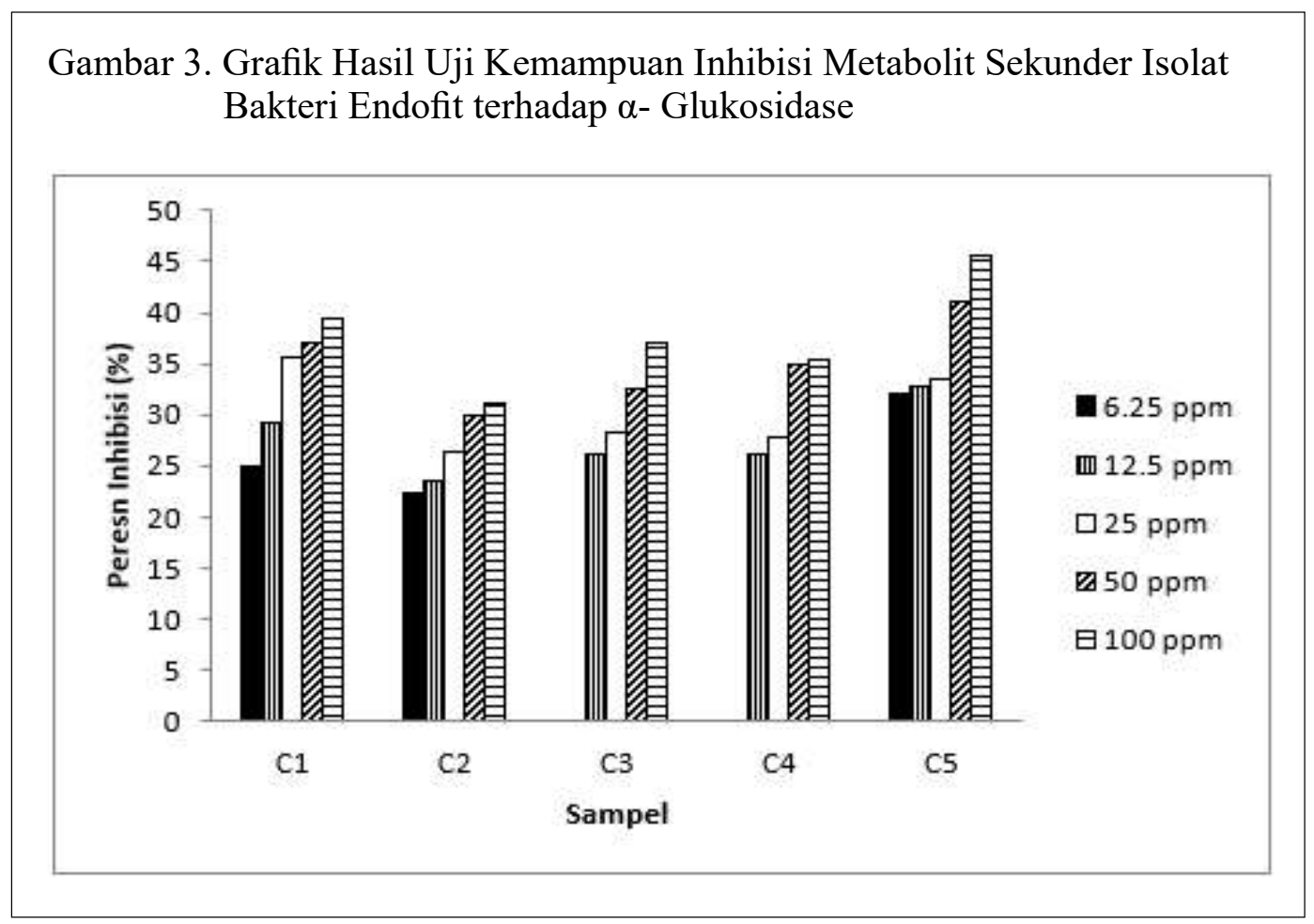

murni akarbosa yang telah terbukti dapat menginhibisi $\alpha$-glukosidase melalui mekanisme inhibitor kompetitif. Adapun sampel padatan metabolit sekunder untuk uji inhibisi $\alpha$-glukosidase merupakan hasil pemekatan dari ekstrak kasar yang berupa senyawa campuran sehingga kemampuan inhibisinya kurang optimal.

Gambar 3 menunjukkan bahwa besarnya nilai inhibisi dipengaruhi oleh tingginya konsentrasi senyawa inhibitor. Semakin tinggi konsentrasi senyawa inhibitor akan semakin besar pula kemampuan inhibisinya meskipun tidak dengan kenaikan yang signifikan. Hal ini dikarenakan senyawa inhibitor dari metabolit sekunder dimungkinkan memiliki kemampuan untuk berkompetisi dengan substrat untuk berikatan dengan enzim sehingga menghambat proses terbentuknya kompleks enzim substrat dan mengakibatkan berkurangnya jumlah produk reaksi enzimatis yang dihasilkan. Mekanisme inhibisi tersebut dinamakan proses inhibisi kompetitif (Poedjiadi, 1994).

Senyawa inhibitor dari metabolit sekunder juga dimungkinkan memiliki kemampuan untuk berikatan dengan enzim atau kompleks enzim substrat. Ikatan tersebut akan mengubah konformasi sisi aktif enzim dan menghambat terbentuknya produk reaksi enzimatis. Mekanisme penghambatan tersebut dinamakan proses inhibisi nonkompetitif dan inkompetitif. (Poedjiadi, 1994). Proses inhibisi kompetitif, 
nonkompetitif, dan inkompetitif akan berlangsung optimal apabila konsentrasi inhibitor tinggi, karena konsentrasi inhibitor yang tinggi akan memperbesar peluang inhibitor untuk menutup sisi aktif enzim ataupun berikatan dengan enzim dan kompleks enzim substrat.

Hasil pengujian menunjukkan bahwa besarnya nilai inhibisi dipengaruhi oleh tingginya konsentrasi senyawa inhibitor. Semakin tinggi konsentrasi senyawa inhibitor akan semakin besar pula kemampuan inhibisinya, meskipun tidak dengan kenaikan yang signifikan. Kenaikan kemampuan inhibisi ini dikarenakan senyawa inhibitor dari metabolit sekunder dimungkinkan memiliki kemampuan untuk menghambat aktivitas enzim secara kompetitif, nonkom-petitif, ataupun inkompetitif. Proses inhibisi kompetitif, nonkompetitif, dan inkompetitif akan berlangsung optimal apabila konsentrasi inhibitor tinggi, karena konsentrasi inhibitor yang tinggi akan memperbesar peluang inhibitor untuk menutup sisi aktif enzim ataupun berikatan dengan enzim dan kompleks enzim substrat.

Pada Gambar 3 juga dapat dilihat bahwa kenaikan dari kemampuan inhibisi pada tiap kenaikan konsentrasi tidak linier. Kemampuan inhibisi dari metabolit sekunder isolat C5 pada konsentrasi 6,25 ppm tidak terpaut jauh dengan kemampuan inhibisi pada konsentrasi 100 ppm. Oleh karena itu dari data kemampuan inhibisi dapat diperoleh informasi bahwa konsentrasi optimal untuk aktivitas inhibisi dari metabolit sekunder isolat $\mathrm{C} 5$ adalah 6,25 ppm.

Penapisan Fitokimia. Tujuan dari penapisan fitokimia adalah mengetahui senyawa metabolit sekunder yang berpengaruh pada proses inhibisi enzim $\alpha$-glukosidase. Senyawa metabolit sekunder ini didapat pada tahap kultur pertumbuhan bakteri endofit kulit kayu manis. Sampel penapisan pada tahap ini adalah hasil dari tahap kultur pertumbuhan bakteri endofit yang telah dikeringkan melalui proses freeze drying. Simplisia kulit kayu manis digunakan sebagai pembanding pada tahap penapisan fitokimia ini untuk mengetahui kandungan kimia awal dari kayu manis sampel dan selanjutnya dibandingkan dengan kandungan kimia dari metabolit sekunder bakteri endofit kulit kayu manis. Hasil dari penapisan fitokimia dapat dilihat pada Tabel 4.

Pada hasil penapisan fitokimia penelitian ini terdapat beberapa senyawa dari tumbuhan inang yang tidak mampu dihasilkan oleh isolat mikroba endofit kulit kayu manis. Nofiani, Nurbetty, dan Sapar (2009) menyatakan bahwa terdapat dugaan bahwa isolat tersebut memiliki gen pengkode pembentukan senyawa metabolit sekunder, namun tidak terekspresi pada media produksi yang digunakan. Gen 
Tabel 4

Hasil Penapisan Fitokima Senyawa Metabolit Sekunder

Isolat Bakteri Endofit Kayu Manis (Cinnamomun

burmanii)

\begin{tabular}{ccccccc}
\hline \multirow{2}{*}{ Jenis Uji } & \multicolumn{7}{c}{ Hasil } \\
\cline { 2 - 7 } & C1 & C2 & C3 & C4 & C5 & Simplisia \\
\hline Alkaloid & - & - & - & - & - & - \\
Flavonoid & + & - & - & - & + & + \\
Kuinon & + & + & - & - & + & + \\
Saponin & + & + & - & + & + & + \\
Terpenoid/Steroid & - & - & - & - & - & + \\
Tanin & + & + & + & + & + & + \\
\hline
\end{tabular}

tersebut baru terekspresi ketika diinduksi terlebih dahulu. Pada media produksi yang digunakan kemungkinan tidak ada induser untuk mengekspresikan gen pembentukan senyawa metabolit sekunder.

Senyawa metabolit sekunder dari isolat $\mathrm{C} 5$ dan $\mathrm{C} 1$ merupakan senyawa dengan penghambatan tertinggi mengandung golongan senyawa flavonoid dan tanin. Senyawa golongan flavonoid dan tanin memiliki kemampuan sebagai penghambat $\alpha$-glukosidase (Adisakwattana, Lerdsuwankij, Poputtachai, Minipun, \& Suparpprom, 2011; Shihabudeen, Priscilla, \& Thirumurugan, 2011). Beberapa flavonoid, seperti morin, luteolin, baicalein, kaempferol dan apigenin, telah terbukti menunjukkan efek penghambatan terhadap enzim a-glukosidase. Diduga bahwa gugus polihidroksil yang memiliki peran penting dalam menghambat enzim a-glukosidase (Proença et al.,2017).

\section{SIMPULAN}

Diperoleh lima isolat bakteri endofit dari kayu manis (isolat $\mathrm{C} 1$, isolat $\mathrm{C} 2$, isolat $\mathrm{C} 3$, isolat $\mathrm{C} 4$, dan isolat $\mathrm{C}$ ). Isolat bakteri yang diperoleh memiliki bentuk beragam yakni streptobacillus (isolat $\mathrm{C} 1$, isolat $\mathrm{C} 4$, dan isolat $\mathrm{C} 5$ ), diplobacillus (isolat $\mathrm{C} 2$ ), dan diplococcus (isolat $\mathrm{C} 3$ ). Adapun kelima isolat bakteri tersebut mampu menghasilkan metabolit sekunder dengan kemampuan sebagai inhibisi $\alpha$-glukosidase. Penapisan fitokimia pada penelitian ini menunjukkan bahwa metabolit sekunder isolat C5 yang memiliki kemampuan inhibisi tertinggi mengandung senyawa flavonoid, tanin, kuinon, dan saponin.

\section{DAFTAR PUSTAKA}

Adisakwattana, S., Lerdsuwankij, O., Poputtachai, U., Minipun, A., \& Suparpprom, C. (2011). Inhibitory activity of cinnamon bark species and their combination effect with acarbose against intestinal $\alpha$-glucosidase and 
pancreatic $\alpha$-amylase. Plant Foods for Human Nutrition, 66, 143-148.

Anjum, V., Ansari, S. H, Naquvi, K. J., \& Arora, P. A. (2013). Development of quality standards of carica papaya linn leaves. Der Pharmacia Lettre, 5(2), 370-376.

Cappuccino, J. G., \& Sherman, N. (1992). Microbiology a laboratory mannual. New York: The Benjamin/Cumming Publishing Company.

Chen, H., Yan, X., Lin, W., Zheng, L., \& Zhang, W. (2004). A new method for screening a-glucosidase inhibitors and application to marine microorganisms. Pharmaceutical biology, 42(6), 416421.

Depkes RI. (2005). Pharmateutical care diabetes mellitus. Jakarta: Direktorat Jenderal Kefarmasian dan Alat Kesehatan, Departemen Kesehatan RI

Farnsworth, N. R. (1966). Biological and phytochemical screening of plants. Journal of pharmaceutical sciences, 55(3), 225-276.

Guo, B., Wang, Y., Sun, X., \& Tang, K. (2008). Bioactive natural products from endophytes: A review. Applied Biochemistry and Microbiology, 44(2), 136-142.

Kafur, A., \& Khan, A. B. (2011). Isolation of endophytic actinomycetes from Catharanthus roseus (L.) G. Don leaves and their antimicrobial activity. Iranian Journal of Biotechnology, 9(4), 302-306.

Kumala, S., Utji, R., Sudarmono, P. P., \& Kardono, L. B. (2006). Isolation of endophytic fungi from Brucea javanica L.(Merr.) and cytotoxic evaluation of their n-butanol extract from fermentation broth. Pakistan Journal of Biological Sciences, 9(5), 825-832

Nurkanto, A., Rahmansyah, M., \& Kanti, A. (2008). Seri panduan teknik isolasi aktinomisetes. Jakarta: LIPI Press.

Ngadiwiyana, Ismiyarto, Prasetya, N. B. A., \& Purbowatiningrum, R. S. (2011). Potensi sinamaldehid hasil isolasi minyak kayu manis sebagai senyawa antidiabetes. Majalah Farmasi Indonesia, 22(1), 9-14.

Nofiani, R., Nurbetty, S., \& Sapar, A. (2009). Antimicrobial activities of methanol extract from unidentified sponge associated bacteria in Lemukutan Island, Kalimantan Barat. Jurnal Ilmu dan Teknologi Kelautan Tropis, 1(2), 33-41.

Nair, D. N., \& Padmavathy, S. (2014). Impact of endophytic microorganisms on plants, environment and humans. The Scientific World Journal, 2014.

Pelczar, M. J., \& Chan, E. C. S. (2008). Dasar-dasar mikrobiologi. (Terj.: Ratna Sari Hadioetomo dkk.). Jakarta : Universitas Indonesia.

Pimentel-Elardo, S. M., Kozytska, S., Bugni, T. S., Ireland, C. M., Moll, H., \& Hentschel, U. (2010). Anti-parasitic compounds from Streptomyces sp. strains isolated from Mediterranean sponges. Marine drugs, 8(2), 373-380. doi:10.3390/md8020373.

Ping, H., Zhang, G., \& Ren, G. (2010). Antidiabetic effects of cinnamon oil in diabetic KK-Ay mice. Food and chemical toxicology, 48(8-9), 23442349.

Poedjiadi, A. (1994). Dasar-dasar biokimia. Jakarta: UI-Press.

Proença, C., Freitas, M., Ribeiro, D., Oliveira, E. F., Sousa, J. L., Tomé, S. M., ... \& Fernandes, E. (2017). a-Glucosidase inhibition by flavonoids: an in vitro and in silico structure-activity relationship study. Journal of Enzyme Inhibition and Medicinal Chemistry, 32(1), 12161228.

Pujiyanto, S., \& Ferniah, R. S. (2010). Aktivitas inhibitor alpha glukosidase bakteri endofit PR-3 yang diisolasi dari tanaman pare (Momordica charantia), BIOMA, 12(1), 1-5.

Pujiyanto, S., Lestari, Y., Suwanto, A., Budiarti, S., \& Darusman, L. K. (2012). Alpha-glucosidase inhibitor activity and characterization of endophytic actinomycetes isolated from some 
Indonesian diabetic medicinal plants. Int J Pharm Pharm Sci, 4(1), 327-333.

Radji, M. 2005. Peranan Bioteknologi dan Mikroba Endofit dalam Pengembangan Obat Herbal, Majalah Ilmu Kefarmasian, 2:113-126.

Sancheti, S., Sancheti, S., \& Seo, S. (2009). Chaenomeles sinensis: A potent $\alpha$-and $\beta$-glucosidase inhibitor. American Journal of Pharmacology and Toxicology, 4(1), 8-11. doi.org/10.3844/ ajptsp.2009.8.11.

Shihabudeen, H. M. S., Priscilla, D. H., \& Thirumurugan, K. (2011). Cinnamon extract inhibits $\alpha$-glucosidase activity and dampens postprandial glucose excursion in diabetic rats. Nutrition \& Metabolism, 8(1), 46.
Strobel, G., \& Daisy, B. (2003). Bioprospecting for microbial endophytes and their natural products. Microbiology and molecular biology reviews, 67(4), 491-502.

Subroto, M. A. (2006). Ramuan herbal untuk diabetes mellitus. Jakarta: Penebar Swadaya.

Sugiwati,S.,2005Aktivitas antihiperglikemik dari ekstrak buah mahkota dewa (Phaleira macrocarpa) sebagai inhibitor alfaglukosidase, Tesis, Institut Pertaian Bogor

Vangalapati, M., Satya, N. S., Prakash, D. S., \& Avanigadda, S. (2012). A review on pharmacological activities and clinical effects of cinnamon species. Research Journal of Pharmaceutical, Biological and Chemical Sciences, 3(1), 653-663. 